\title{
A BEHAVIORAL ENGINEERING: FRAUD PREVENTION IN ACCOUNTING STUDENTS WITH THE INVOLVEMENT OF RELIGIOUS MOTIVATION
}

\author{
Mas Nur Mukmin \\ Accounting Department, Faculty of Economic \\ Universitas Djuanda, Bogor-Indonesia
}

\begin{abstract}
This research conducts to determine the practice of academic cheating by raising one component of diamond fraud, namely, opportunity. The involvement of religious motivation is expected to be a deterrent variable in suppressing the influence of opportunity on the practice of academic cheating among accounting students. This research was conducted on 235 samples of accounting students registered in the Bogor, West Java, Indonesia. By using quantitative descriptive methods, this study successfully revealed the role of spiritual motivation in the relationship between opportunity and academic cheating. Following the diamond fraud theory, this study revealed the positive influence of opportunity variables on the practice of academic fraud among accounting students. The existence of spiritual motivation is proven to reduce the correlation coefficient between opportunity and academic cheating. This study requires experimental social research on the object of research, namely accounting students, to see the practice of treating the variables studied.
\end{abstract}

Keywords: Academic Cheating, Academic Dishonesty, Accounting Student, Diamond Fraud, Fraud Prevention, Opportunity, Religious Motivation.

Cite this Article: Mas Nur Mukmin, A Behavioral Engineering: Fraud Prevention in Accounting Students with the Involvement of Religious Motivation. International Journal of Civil Engineering and Technology 11(1), 2020, 112-118.

http://iaeme.com/Home/issue/IJCIET?Volume=11\&Issue=1

\section{INTRODUCTION}

\subsection{Background}

Fraud is an act that is sure to harm others and only gives benefits to those who cheat. In accounting science, common fraud is committed by the parties concerned in preparing financial statements. Thus, it is evident that the parties involved in the preparation are internal and external parties such as public accounting firms. Preventive measures need to be taken so that fraud in the world of accounting science can be minimized. There have been many real cases of fraud in accounting science that have proven to be detrimental to the whole world, 
call it a case involving a large company of Enron's class or a well-known public accounting firm, Arthur Anderson. The case is clear evidence that fraud committed by accounting experts can trigger a global financial crisis due to a structured and systematic manipulation of the reporting of a financial statement to the public.

Prevention efforts can be made to students who will become prospective accountants in the future. Some facts that have been revealed by previous studies that in several institutions of higher education, almost $82 \%$ of the sample of college graduates claimed to commit academic fraud as students [1]. This shows that the process that accountants went through while still being a student in college went through a phase of fraudulent behavior. This behavior requires special attention, especially cheating, that is repeated until practiced at work. Another recent study reported that $95 \%$ of all students admitted cheating in some way while at school [2]. Fraud Diamond's theory reveals that fraud is divided into planned fraud and incidental fraud. For example, fraud diamond theory reveals that opportunities to cheat can make someone cheat unplanned in advance. This happens because the perpetrators see the more benefits that can be obtained when the opportunity to cheat appears. Students who commit academic cheating while in college are also more likely to commit fraud in the workforce. A 10-year study of homogeneous and constant samples, namely students entering the workforce, successfully revealed that samples that cheated while completing their studies in college tended to commit fraud while working [3]. There is a relationship between students who commit despicable behavior and tend to do it while in the workforce [4]. This shows that prevention needs to be done from the beginning even since these professional accountants are still students. This is done so that accounting knowledge is not littered with the need to cheat some people who are not responsible or have personal interests and override integrity as an accountant. Theft committed by employees is the main source of loss from crime in business [5]. As many as $48.8 \%$ of employees confess that they are tempted to use company equipment at least once during the past year.

Besides, some data related to fraud in acts of corruption that are still high in Indonesia needs to be a concern of academics, notably contributing to producing graduates who do not have high integrity, morality and work ethics. The role of universities in preventing the emergence of accountants or workers who commit fraud in the world of work needs to be given special attention.

This research tries to find the right formula with the accuracy of the methods that can be used by universities in contributing to efforts to prevent fraudulent practices carried out in the world of accountants. Transparency International Indonesia (TII, 2017) said that Indonesia's Corruption Perception Index (CPI) in 2016 was 37, ranking 90th out of 176 countries. The CPI score is in the range of $0-100$, which means that 0 countries are perceived to be very corrupt, while scores of 100 countries are perceived to be very clean. Among Asian countries, Indonesia's score is still below Malaysia (49 points), Brunei (58 points), and Singapore (85 points). The score shows that corruption cases in Indonesia are still high compared to other Asian countries.

\subsection{Research Purpose}

Thus, research is needed that can identify the inhibiting / preventing factors of academic fraud among accounting students. Through fraud diamond theory, this research tries to look deeper into the dimensions of opportunity contained therein, which is one of the leading causes of actions that are detrimental to others. Opportunity is even seen as a boundary between integrity and disintegrate, which is the gateway for determining an individual's ethics. Not cheating because they cannot cheat or do not cheat because there is not a chance, and maybe cheat when the opportunity exists. 
A Behavioral Engineering: Fraud Prevention in Accounting Students with the Involvement of Religious Motivation

\section{MATERIALS \& METHODS}

\subsection{Materials}

In realizing a target or achievement, an individual needs motivation [6]. Being a person of integrity, high morale, and good work ethics involve a motivation to build a personal character that reflects these three things. Motivation addresses the power and potential within the person in order to achieve the targets that have also been set goals that have been determined [7]. Motivation is the process of initiating awareness and meaningful action. Motivation is an essential key to initiating, controlling, supporting, and directing behavior. Motivation is also related to subjective reactions that arise during this process. Motivation is an essential concept for discussing behavioral problems because organizational effectiveness depends on people doing the work they are expected to do. Motive is the single factor that fosters the process of motivational motives that are personal. For example, someone who comes from a wealthy family usually looks for work that gives meaning to acceptance and well-being, while other people who come from underprivileged families usually look for work that provides freedom from economic bondage and increases the family's dignity. Motivation is influenced by needs and expectations [8].

In connection with aspects of meeting human needs in matters of religion and worship, human needs are divided into physical needs and spiritual needs, then human behavior is not only motivated to meet physical needs, but also human behavior is motivated to meet spiritual or spiritual needs. These motivations that motivate human behavior to fulfill spiritual needs are what are then called religious motivations. Muslim's spiritual motivation is divided into 3 (three), namely: Motivation of Belief, Motivation of Worship, and Motivation of Relationship with God [9]. No religious teachings allow cheating or harming others. This doctrine is seen as an appropriate formula in building the integrity, morals, and ethics of students in preventing cheating, even when opportunities are available in plain sight.

\subsection{Methods}

This study aims to determine the effect of opportunity on academic fraud with religious motivation as a moderating variable. The research method used is descriptive qualitative and quantitative research, with the aim is to increase understanding or update existing theories. This research was conducted on accounting students in the city area of Bogor, West Java Province, Indonesia. The study was conducted by distributing questionnaires to 235 accounting students as respondents. Data testing was performed using validity and reliability tests. Data processing to get the result of research is done by using Moderating Regression Analysis (MRA).

\section{RESULT \& DISCUSSION}

\subsection{Result}

The results of research conducted in accordance with the research plan, then the following is an explanation of the research findings as follows: At the initial data collection stage, a survey was conducted on several universities, which were the object of research, including Djuanda University and STIE Tazkia. The survey was conducted on a total of 235 respondents. The total questionnaire that can be used is 218 respondents. A total of 17 questionnaires could not be processed further because there were some items that were not filled.

Based on the questionnaire that can be processed, the following are the characteristics of respondents in this study: 
Mas Nur Mukmin

Table 1 Sample's Demographic by Gender

\begin{tabular}{ccc}
\hline Gender & Year & Percentage \\
\hline 1 & 64 & $29 \%$ \\
2 & 154 & $71 \%$ \\
\hline Total & 218 & $100 \%$ \\
\hline
\end{tabular}

Table 2 Sample's Demographic by Age

\begin{tabular}{ccc}
\hline Age & Amount & Percentage \\
\hline 18-20 years old & 23 & $11 \%$ \\
21-23 years old & 177 & $81 \%$ \\
24-26 years old & 18 & $8 \%$ \\
>27 years old & 0 & $0 \%$ \\
\hline Total & 218 & $100 \%$ \\
\hline
\end{tabular}

Table 3 Sample's Demographic by Student Batch/Semester

\begin{tabular}{ccc}
\hline Batch/Semester & Amount & Percentage \\
\hline $2015 / 8$ & 91 & $42 \%$ \\
$2016 / 6$ & 84 & $38 \%$ \\
$2017 / 4$ & 43 & $20 \%$ \\
\hline Total & 218 & $100 \%$ \\
\hline
\end{tabular}

Based on the results of the validity and reliability test (using Cronbach alpha) on the measurement of variables using a questionnaire, the following results are obtained:

Table 4 Test of Validity

\begin{tabular}{lccc}
\hline \multicolumn{1}{c}{ Variable } & $\mathbf{r}_{\text {count }}$ & $\mathbf{r}_{\text {table }}$ & Decision \\
\hline Opportunity & 0,857 & 0,3 & Valid \\
Academic Fraud & 0,784 & 0,3 & Valid \\
Religious Motivation & 0,655 & 0,3 & Valid \\
\hline
\end{tabular}

Table 5 Test of Reliability

\begin{tabular}{lccl}
\hline \multicolumn{1}{c}{ Variable } & $\mathbf{r}_{\text {count }}$ & $\mathbf{r}_{\text {table }}$ & Decision \\
\hline Opportunity & 0,819 & 0,6 & Reliable \\
Academic Fraud & 0,688 & 0,6 & Reliable \\
Religious Motivation & 0,778 & 0,6 & Reliable \\
\hline
\end{tabular}

Moderated Regression Analysis (MRA) or often called the interaction test, is a unique application of multiple linear regression where the regression equation contains interaction 
A Behavioral Engineering: Fraud Prevention in Accounting Students with the Involvement of Religious Motivation

elements (multiplication of two or more independent variables) [10]. The results of moderate regression analysis can be seen in Table 6 below:

Table 6 Moderate Regression Analysis

\begin{tabular}{cccccc}
\hline Model & B & Std. Error & Beta & T & Sig. \\
\hline (Constant) & 0,536 & 0,240 & & 2,234 & 0,027 \\
X & 0,453 & 0,123 & 0,248 & 3,551 & 0,000 \\
XZ & $-0,591$ & 0,053 & $-0,776$ & $-11,128$ & 0,000 \\
\hline
\end{tabular}

Based on Table 6 above, it is known that the value of the regression equation is as follows:

$$
\begin{aligned}
& y=a+\beta 1 X+\beta 2 X Z+\varepsilon \\
& y=0,536+0,435 X-0,591 X Z+{ }^{\varepsilon}
\end{aligned}
$$

The interpretation of the regression is a constant of 0.536 , meaning that if the independent variable is assumed to be 0 , then the Academic Fraud will constantly be valued at 0.536 . The regression coefficient $\mathrm{X}$ of 0.435 means that opportunity has a positive effect on Academic Fraud. This shows that with the addition of one unit of opportunity, there will be an increase in Academic Fraud of 0.435. XZ regression coefficient of 0.591 means that the interaction between opportunity and religious motivation weakens Academic Fraud. It shows that by adding one unit of interaction between opportunity and religious motivation, there will be a decrease in Academic Fraud of 0.591.

The coefficient of determination is done to determine the magnitude of the contribution of the opportunity variable and religious motivation to academic fraud. The coefficient of determination is obtained by squaring the correlation coefficient that has been found, and then multiplied by $100 \%$ or can also directly see the value of R Square (R2). The results of the analysis of the coefficient of determination can be seen in the following Table:

Table 7 Moderate Regression Analysis

\begin{tabular}{ccccc}
\hline Model & $\mathbf{R}$ & $\mathbf{R}^{2}$ & $\begin{array}{c}\text { Adjusted } \\
\mathbf{R}^{2}\end{array}$ & $\mathbf{T}$ \\
\hline $1(\mathrm{X}, \mathrm{Y})$ & 0,665 & 0,442 & 0,434 & 1,443 \\
$2(\mathrm{X}, \mathrm{XZ}, \mathrm{Y})$ & 0,647 & 0,416 & 0,413 & 1,469 \\
\hline
\end{tabular}

Based on Table 7 above it can be concluded for the first regression that is the opportunity variable, and religious motivation obtained R2 (R Square) of 0.442 or (44.2\%) and decreased to 0.416 or $41.6 \%$ after being moderated between the opportunity variable and religious motivation, with this can be interpreted by the moderating variable, namely religious motivation, which will weaken the relationship between opportunity and academic fraud.

\subsection{Discussion}

Based on the results of testing, the opportunity variable (X) partially influential and significant on academic cheating. This means that great opportunities can increase student 
academic cheating. Respondents 'answers about opportunities indicated that students' perceptions of opportunities varied greatly.

This is indicated by the respondent's answers that are evenly distributed on all answer choices in all indicator questions, the respondent's response to the statement of cheating opportunities when the test is more significant for students sitting in the back shows high interpretation values, and the respondent agrees with the statement that opportunity can encourage students to do cheat [11].

About opportunity, students tend to wait for opportunities when they are not ready to take the exam [12]. It is relevant to research that shows opportunity has a positive effect on academic cheating conducted by students [3].

The opportunity to cheat when facing an exam tends to be done by students because of a lack of confidence in the answers that make students commit fraudulent actions by cheating on their friends' answers [8], [13].

Based on the results of testing, the religious motivation variable $(\mathrm{Z})$ weakens the relationship between the opportunity for academic cheating. Religious motivation becomes a very important factor in shaping the character of students to support the integrity, morals, and work ethics. The factor of spiritual motivation is influenced by a desire or impulse to do something to achieve the goal in terms of actualizing the teachings of his religion. This is shown by the response of respondents regarding the statement of belief that God sees what we do, either openly or secretly. Not cheating is a form of carrying out religious orders and avoiding prohibitions. Religious motivation is considered as a person's relationship with his religion or belief, so the more students deepen their beliefs, religious motivation becomes a force that encourages someone to do something that does not violate the values of belief, including cheating, at any opportunity [14], [15]. Thus, the existence of religious motivation in everyone will certainly create an academic atmosphere without cheating and is expected to prevent cheating practices in the workplace [16], [17].

\section{CONCLUSION}

Based on the results of the study above, it can be concluded that religious motivation weakens the effect of opportunity on academic fraud among accounting students.

\section{ACKNOWLEDGEMENTS}

The authors wish to thank to Universitas Djuanda for the research grant. This work was supported by the Directorate of Research and Community Empowerment of Universiats Djuanda.

\section{REFERENCES}

[1] Pardo, Alfonso, and Carlos Rodríguez-Casals. "Academic fraud at the university: An analysis of an actual case, the conflict and its resolution." education policy analysis archives 27 (2019): 40.

[2] Horton, Joanne, Dhanya Krishnakumar, and Anthony Wood. "Detecting Academic Fraud in Accounting Research: The Case of Professor James Hunton." Available at SSRN 3164961 (2018).

[3] Nonis, Sarath, and Cathy Owens Swift. "An examination of the relationship between academic dishonesty and workplace dishonesty: A multicampus investigation." Journal of Education for business 77.2 (2001): 69-77.

[4] Burke, Debra D., and Kenneth J. Sanney. "Applying the fraud triangle to higher education: ethical implications." Journal of Legal Studies Education 35.1 (2018): 5-43. 
A Behavioral Engineering: Fraud Prevention in Accounting Students with the Involvement of Religious Motivation

[5] Boyle, Douglas M., James F. Boyle, and Brian W. Carpenter. "Accounting student academic dishonesty: What accounting faculty and administrators believe." The Accounting Educators' Journal 26 (2017).

[6] Burke, Debra D., and Kenneth J. Sanney. "Applying the fraud triangle to higher education: ethical implications." Journal of Legal Studies Education 35.1 (2018): 5-43.

[7] Artani, Ketut Tri Budi. "Academic Fraud Behaviour Among Students in Accounting Diploma Program: An Empirical Study in Bali." KnE Social Sciences (2018): 37-45.

[8] Dephiena, S. (2017). Understanding The Meaning And Motivation Of Academic Fraud: An Exploration On Accounting Students. Jurnal Ilmiah Mahasiswa FEB, 5(2).

[9] Muhsin, Mr, et al. "An Analyis of Student's Academic Fraud Behavior." International Conference on Learning Innovation (ICLI 2017). Atlantis Press, 2017.

[10] Rahman, Nor Hawani Wan Abdul, et al. "Students' Cheating Behaviour in Higher Education System: Reconnoitring the Academic Integrity from the Accounting Students Perspectives." Regional Conference on Science, Technology and Social Sciences (RCSTSS 2014). Springer, Singapore, 2016.

[11] Shore, Cris. "How corrupt are universities? audit culture, fraud prevention, and the Big Four accountancy firms." Current Anthropology 59.S18 (2018): S92-S104.

[12] Alleyne, Philmore, and Renée M. Thompson. "Examining Academic Dishonesty: Implications for Future Accounting Professionals." Prevention and Detection of Academic Misconduct in Higher Education. IGI Global, 2019. 159-183.

[13] Yussof, Salwa Hana, and Suhaiza Ismail. "Academic Dishonesty Among Accounting Students in Malaysia." Management \& Accounting Review (MAR) 17.1 (2018): 19-46.

[14] Kusuma, Indra Cahya, Rachmi Nurfitri, and Mas Nur Mukmin. "Pengaruh Pressure, Opportunity, Rasionalization Dan Capability Terhadap Kecenderungan Kecurangan Akuntansi (Fraud)." JURNAL AKUNIDA 5.1 (2019): 54-68.Ambraseys, N. N., Melville, C. P. A History of Persian Earthquakes. Britain: Cambridge University Press, 1982, pp. 219.

[15] Koerber, Charles P., and Christopher P. Neck. "Religion in the workplace: Implications for financial fraud and organizational decision making." Journal of Management, Spirituality \& Religion 3.4 (2006): 305-318.

[16] Stavrova, O., \& Siegers, P. (2014). Religious prosociality and morality across cultures: How social enforcement of religion shapes the effects of personal religiosity on prosocial and moral attitudes and behaviors. Personality and Social Psychology Bulletin, 40(3), 315-333.

[17] Said, Jamaliah, et al. "Integrating Religiosity into Fraud Triangle Theory: Findings on Malaysian Police Officers." (2019). 